\title{
A New Alliance in New York State: A Progress Report on the Labor Movement's Restructuring, Capacity Building and Programmatic Work
}

\author{
Jeff Grabelsky
}

\begin{abstract}
The labor movement in New York State has undergone a dramatic restructuring that is part of a national AFL-CIO program called the New Alliance. The purpose of the New Alliance is to build the capacity of local labor movements and empower unions to help shape a region's political and economic agenda. The restructuring in NYS led to the consolidation of 25 central labor councils into 5 area labor federations, each of which is developing the resources, staff and leadership to help grow labor's regional power across the state. This article describes the origins of the New Alliance, the nature of the restructuring process, the ways in which the capacity of local labor movements are expanding, the programmatic work the restructured central bodies have undertaken in the last five years, and the impact of the national split on local and regional central bodies across New York State.
\end{abstract}

\section{Introduction}

In the summer of 1999, Denis Hughes, president of the New York State AFLCIO, and Al Davidoff, NYS director for the national AFL-CIO, conducted a nine-city “listening tour" to confer with local union leaders and to learn more about the activities of the thirty-one central labor councils scattered across the state. The tour was part of a larger effort to develop a strategic plan for the state federation. In one small city, Hughes and Davidoff met with a long-time CLC president and asked him what he regarded as his central labor council's greatest accomplishment during the past year. "Establishing a 'labor hole’ at a local charity’s miniature golf tournament,' the CLC president responded. That may have been one of the first clear indications that changes in the structure and function of New York State’s central labor bodies might be necessary. ${ }^{1}$

The listening tour was the first decisive step in New York State's New Alliance initiative, a national AFL-CIO program that eventually consolidated 25 central labor

\footnotetext{
${ }^{1}$ Interview with Al Davidoff, September 29, 2005. Interview with Denis Hughes, April 26, 2006.
} 
councils into five large area labor federations. This article describes the origins of the New Alliance, the nature of the restructuring process, the ways in which the capacity of local labor movements was expanded, the programmatic work the restructured central bodies have undertaken in the last five years, and the impact of the national split on local and regional central bodies across New York State.

After 1995, when John Sweeney was elected AFL-CIO president in the first contested election in recent federation history, his administration injected new hope and energy into what many observers considered to be a moribund movement. Sweeney’s team was determined to grow the ranks of organized labor, strengthen its political voice, and help spark a progressive movement. Capable staff were recruited to devise and implement new programs for organizing, mobilization, and politics.

A key aspect of Sweeney's efforts to revitalize the labor movement was the transformation of the old Department of Field Services into a dynamic Field Mobilization Department. Headed by Marilyn Sneiderman, the newly rejuvenated department was charged with building the capacity of local labor movements and driving federation activities where they mattered most: in the field. A series of new initiatives were rolled out, including Union Cities, which was designed to enhance the effectiveness and elevate the programmatic work of central labor councils in targeted cities. These new initiatives were promoted by progressive CLC leaders in the field, like San Jose’s Amy Dean and Seattle’s Ron Judd, and embraced by national AFL-CIO leaders, including John Sweeney and Linda Chavez Thompson. The combination of grassroots energy and top-down direction gave programs like Union Cities some traction in a number of regions across the country. But at the end of the day, Field Mobilization experienced mixed success with its 
Union Cities program. In its essence, Union Cities outlined what CLCs should do, without addressing the variety of obstacles - structural, financial, and other - that prevented CLCs from functioning at a higher level. In some places, like Denver and Seattle, central bodies embraced the program with enthusiasm and worked hard to transform their towns into true union cities. But in other places, central labor councils were designated as Union Cities candidates without fundamentally changing their operations. It became clear that the talent and tenacity of Field Mobilization staff and the energy and determination of local leaders were not enough to overcome a range of barriers that could only be overcome with a more comprehensive approach. ${ }^{2}$

The AFL-CIO established a CLC Advisory Committee, comprised of key central body leaders from across the country, in order to monitor, assist and evaluate efforts to revitalize local labor movements. By 1999, the AFL-CIO had decided to initiate a new effort to build on the initial success and to address the recurring frustrations of the Union Cities program. The New Alliance initiative would examine the structure of statewide labor movements, analyze the functionality of central bodies, evaluate why local unions did or did not affiliate and participate in those bodies, and propose changes that would enable local labor movements to become more relevant and vital players in regional affairs.

New York was the first state to engage in the New Alliance process. In March, 1999, Denis Hughes was elected NYS AFL-CIO President and took the helm of a labor movement where $26.5 \%$ of the statewide workforce was unionized. But even though New York's labor movement was among the strongest in the nation, Hughes and other labor leaders recognized that the level of statewide unionization was steadily declining

\footnotetext{
${ }^{2}$ Interview with Al Davidoff, September 29, 2005 and October 20, 2006.
} 
and the power and influence of organized labor in New York were gradually eroding. President Hughes was committed to revitalizing the statewide movement and saw New Alliance as an opportunity to help achieve that goal. Hughes persuaded John Sweeney to select New York as the pilot state and he played a key role in guiding the effort. He partnered effectively with Al Davidoff, who had served as the president of the Midstate Labor Council, covering Tompkins and Cortland Counties and based in Ithaca, before being recruited in 1996 to the Field Mobilization staff as its director for New York State. Hughes and Davidoff worked closely with Joe Alvarez, the national AFL-CIO’s Northeast Regional Director, whose vision and support were essential to the success of the New Alliance enterprise. ${ }^{3}$

The story of the New Alliance restructuring in New York State is a positive one. The work of New York's local and regional labor movements is considerably more advanced and effective now than it was before restructuring. At the same time, that work is still in its formative stages; there is much more that can and needs to be done to build labor's regional power throughout NYS. With the help of its CLC Advisory Committee, the national AFL-CIO has devised a model for building central labor bodies that guides them through four stages of organizational development: reacting, mobilizing, powerbuilding, and agenda-driving. ${ }^{4}$ The New York State experience illuminates the meaning of these stages in the real world. Through the New Alliance initiative, central labor bodies in NYS have moved beyond reacting and have been mobilizing more effectively than ever before, especially in their political work. In many places, they have begun to

\footnotetext{
${ }^{3}$ Interview with Denis Hughes, April 26, 2006. Interview with Al Davidoff, September 29, 2005. Interview with Joe Alvarez, April 28, 2006.

${ }^{4}$ See Addendum \#1: AFL-CIO Central Labor Council Organizational Development Matrix. 
enter the power-building phase. In the coming period, the challenge central labor bodies face is to build enough power that they proactively shape and drive a region's agenda.

It should be noted that the split in the labor movement at the national level has disrupted good work at the regional and local levels, distracted leaders from moving that work through the power-building stage toward agenda-driving, and generated frustration and resentment among local and regional leaders whose patience with national leaders appears to be wearing thin.

\section{Restructuring}

The 1999 “listening tour” was eye-opening for President Hughes, State Director Davidoff, and the labor leaders to whom they reported their findings. In general, they discovered that most of New York State's 31 central labor councils were seriously underfunded, understaffed, under-affiliated and underperforming. Most CLCs had part-time officers, many of whom were not even full-time officials in their own unions. These officers were often volunteers who continued to work at their regular jobs while attempting to "lead" the central body. ${ }^{5}$

In some of the state's larger cities or regions - like Buffalo, Rochester, Syracuse, Albany, New York and Long Island - central bodies had an officer who was a paid fulltime union official; but only in New York City, Buffalo and Long Island was the lead officer a full-time central body representative. Very few central bodies had full-time staff members.

As a consequence, many CLCs functioned like social clubs, without programmatic focus or strategic direction. They met regularly, but meetings were sparsely attended and key decision-makers from major affiliates did not generally

\footnotetext{
${ }^{5}$ Interview with Al Davidoff, September 29, 2005. Interview with Denis Hughes, April 26, 2006.
} 
participate in their deliberations. Central labor councils occasionally made donations to their favorite charities, held Labor Day picnics, and offered political endorsements (somewhat indiscriminately or arbitrarily and without much capacity to really help endorsed candidates win elections). Denis Hughes and Al Davidoff could not escape an obvious conclusion: too many of the state's central labor councils were frail and floundering. In most cases, the central bodies had limited capacity to mobilize their members and potential allies and to react to events that impacted workers and their unions. ${ }^{6}$

The central bodies that functioned at higher levels tended to be bigger ones, with a larger membership base and leaders who were focused both on running their own local unions and, at least to some extent, building the local labor movement. But even in those areas, most labor leaders seemed trapped by what might be characterized as "free market trade unionism.” That is, they each pursued the particular and sometimes parochial interests of their own union with the hope and expectation that, if every other affiliate behaved the same way, the invisible hand of "free market trade unionism" would advance the common good of the larger movement. Many leaders now concede that this orientation is not working well. Even in New York, the most densely unionized state in the country, it is becoming increasingly difficult for individual unions to advance their own agendas and, at the same time, organized labor is not growing significantly in size or stature. Whether New Alliance offers an opportunity to transcend this self-limiting brand of trade unionism remains to be seen. ${ }^{7}$

\footnotetext{
${ }^{6}$ Interview with Al Davidoff, September 29, 2005. Interview with Denis Hughes, April 26, 2006.

${ }^{7}$ The concept of "free market trade unionism" emerged out of interviews with key affiliate leaders that were conducted in 2006 under the auspices of the NYS AFL-CIO's Strategic Review and Evaluation Project.
} 
At the time of the listening tour, the structures and jurisdictions of the state's central bodies had not been critically analyzed since they were established a century ago. In some cases, CLC jurisdictions - which may have made sense 50 years ago - no longer logically conformed to economic markets or legislative districts. That mismatch undermined the value and effectiveness of those CLCs. ${ }^{8}$

The New York State AFL-CIO assembled a committee of statewide labor leaders to review the current status of the state's central bodies and to propose a New Alliance plan to restructure and revitalize them. This New Alliance Drafting Committee included AFM 802 President Bill Moriarty, AFSCME CSEA President Danny Donohue, AFSCME DC 37 Administrator Lee Saunders, AFT NYSUT President Thomas Hobart, AFT UFT President Randi Weingarten, APWU 215 President Jim Bertolone, NYC and NYS Building and Construction Trades President Ed Malloy, Constituency Group representative and UNITE International Vice President Clayola Brown, CWA District One Assistant to the VP Peter Maher, Operating Engineers 15 Business Manager Thomas P. Maguire, IBEW International Representative Jerry Comer, HERE 6 President Peter Ward, IBT Joint Council16 President Anthony Rumore, LIUNA Vice President Steve Hammond, OPEIU President Mike Goodwin, RWDSU President Stuart Applebaum, SEIU 1199 President Dennis Rivera, SEIU 32 BJ President Michael Fishman, TWU President Sonny Hall, UFCW 1500 President Frank Meehan, UNITE Executive Vice President Edgar Romney, UAW Region 9 Director Geri Ochocinska, NYC CLC President Brian McLaughlin, Syracuse CLC President Marshall Blake, and NYS

\footnotetext{
${ }^{8}$ Interview with Colleen Gardner, NYS AFL-CIO Director of Organizing, June 14, 2005 and April 25, 2006.
} 
Federation President Denis Hughes. ${ }^{9}$ Based on extensive analysis, discussion and debate, a rough consensus was hammered out around a plan to consolidate 25 CLCs into five regional area labor federations. According to Bruce Colburn, the Deputy Director of Field Mobilization who managed the New Alliance process nationally, New York State's experience was somewhat unique. Unlike other states that participated in New Alliance after New York, the empire state's committee focused less on program and more on structure, carefully mapping out a plan for the restructuring of local labor movements. ${ }^{10}$

The basic idea of the proposed restructuring was to create central bodies whose jurisdictions included enough union members - judged to be about 100,000 - so that sufficient resources could be generated by per capita dues to support and sustain wellfunded, well-staffed, functional area labor federations (ALFs). The central labor councils of Westchester and Putman Counties were merged into a single central labor body. New York City and Long Island were left in tact for a variety of reasons, including the fact that each one had a sufficiently large membership base and consolidation was, therefore, unnecessary. Three councils in New York State's more remote north country did not participate in the New Alliance process because they were judged to be too small to warrant the time and resources required to restructure them. ${ }^{11}$

Of course, once the restructuring was effectuated, unions would have to be persuaded to affiliate with the newly created area labor federation - and existing CLCs within the ALF jurisdiction - and to pay per capita dues on most, if not all, of their

\footnotetext{
${ }^{9}$ The members of the NYS New Alliance Drafting Committee are listed in alphabetical order of international affiliate. Several of these members no longer serve their respective organizations in the positions listed above.

${ }^{10}$ Interview with Bruce Colburn, October 19, 2006. See Addendum \#2 for map of New York State area labor federations and central labor councils.

${ }^{11}$ Interview with Al Davidoff, September 29, 2005.
} 
members. This was one of the most vexing problems revealed by the Hughes-Davidoff listening tour: local unions often decided not to affiliate with central bodies because the CLCs were only marginally functional and added little value to the unions' efforts. In the past, if these unions were persuaded to affiliate, they often declined to pay per capita dues on all of their members. Either way, the CLC was denied sufficient participation and financial support to sustain an effective program and that reality dissuaded other local unions from affiliating. It was a circular dilemma that New York's labor leaders hoped the New Alliance could help resolve. ${ }^{12}$

The New Alliance consensus was somewhat tenuous because some central body leaders, especially those whose power and prerogatives would be diminished through restructuring, resented and resisted the New Alliance process. This was generally more common in regions with larger cities that housed stronger CLCs, like Albany, Syracuse, and Rochester, and less common in regions like the Hudson Valley that lacked a dominant city-based CLC and where local union leaders seemed to be more easily won over to the New Alliance vision. ${ }^{13}$ In some cases, skeptical and defiant local CLC officers contacted the statewide leaders of the affiliate to which they belonged, criticizing and complaining about the restructuring. Many of these statewide leaders served on the New Alliance Drafting Committee President Hughes had convened. Unfortunately, their strong support, which was essential for the restructuring process, could not be assumed. By using their considerable political skills, Denis Hughes, Al Davidoff and Joe Alvarez managed to generate and sustain sufficient support among a core group of influential affiliate leaders to neutralize the pockets of resistance to New Alliance and to drive the

\footnotetext{
${ }^{12}$ Interview with Al Davidoff, September 29, 2005.

${ }^{13}$ Interview with Susan Borenstein, National Field Representative AFL-CIO, July 31, 2006.
} 
restructuring forward. The New Alliance process probably would have been smoother and more efficient if more affiliate leaders had fully appreciated its vital importance to the future of New York State's labor movement. ${ }^{14}$

The evidence appears to be overwhelming that the New Alliance restructuring in New York State created central bodies with greater functional capacity than the existing CLCs had exhibited and that the new formations soon engaged in more meaningful programmatic work as well. New Alliance appears to have opened space for energetic leaders to emerge and shake things up, thus liberating central bodies from tradition-bound thinking. And, it created opportunities to marginally increase the diversity of the local leadership. ${ }^{15}$ In New York State, the New Alliance is a good, but still unfinished story.

\section{Capacity Building}

There are three basic ways that restructuring enhanced the capacity of local labor movements. First, New Alliance helped install and engage active and influential leaders in the newly created area labor federations. Second, it enabled central bodies to hire more highly functional full-time staff. Third, restructuring generated a sufficient financial base from increased per capita dues and expanded affiliations to build additional organizational capacity and support more advanced programmatic work.

First, enlisting more active and influential leaders in the affairs of area labor federations was essential to success. In all they newly created ALFs, presidents and executive boards were initially appointed and eventually elected to provide overall strategic direction, speak publicly for the local labor movement, and to manage sometimes complex area federation politics.

\footnotetext{
${ }^{14}$ Interview with Al Davidoff, September 29, 2005. Interview with Joe Alvarez, April 28, 2006.

${ }^{15}$ For example, in the Westchester-Putnam Central Labor Body, the executive board added to its membership two women, one of color.
} 
Unlike most of the sitting CLC presidents, newly installed ALF officers were all full-time union officials who devoted a significant amount of their time to building the local labor movement. The contributions of key local leaders were not confined to their service as ALF officers. The ALF executive boards gradually managed to engage leaders of most major affiliates operating in the area labor federation's jurisdiction, some of whom - incredibly - didn't even know one another and many of whom had previously regarded CLCs as irrelevant, and thus ignored them. ${ }^{16}$

Second, hiring competent full-time staff was also critical to the success of the newly formed area labor federations. Through the New Alliance restructuring, full-time staff at central bodies across the state increased from 5.5 to over 20. In each of the five area labor federations, as well as the revitalized Long Island Federation of Labor and the Westchester-Putnam Central Labor Body, new staff were hired to coordinate programmatic work and to administer operations. A determined effort was made to recruit staff through a selection process that matched skills and experience with the roles and responsibilities of the newly created ALF staff positions. In general, relatively young and energetic staff were hired who brought both enthusiasm and skills to their new positions. But not all the new staffers were sufficiently experienced to manage the complex political dynamics of a central labor body. More experienced elected leaders helped balance the ALF teams. ${ }^{17}$

Third, establishing a solid financial base to support each area labor federation was a critical challenge that had to be met. Increasing affiliations and raising per capita dues helped accomplish this goal. After the formation of area labor federations, affiliates' per

\footnotetext{
${ }^{16}$ Interview with Susan Borenstein, July 31, 2006.

${ }^{17}$ Interview with Al Davidoff, October 20, 2006. Interview with Amy Desjardins, NYS AFL-CIO Director of Field Services, April 25, 2006.
} 
capita dues to central bodies increased to $\$ .20$ per member per month from the previous statewide average of \$.13. Moreover, eleven international unions significantly increased the affiliations of their locals to central bodies across the state. For example, Danny Donohue, president of the Civil Service Employees Association (CSEA) - the largest AFSCME affiliate in New York State - increased his union’s affiliation rate from $27 \%$ to $100 \%$, adding 220,000 members to central bodies and thus infusing them with an additional \$3-400,000 annually. This was no small feat; it required unusual political courage and determination, demonstrated when President Donohue appealed directly to the delegates of the CSEA convention and called for a dues increase to allow his union to help fund the ALFs. This kind of leadership and intervention helped invigorate the New Alliance. $^{18}$

In virtually every area labor federation, increasing affiliations was an important element of success. For example, the Capital District Area Labor Federation (CDALF) comprised of several counties including and surrounding the state’s capital, Albany, managed to increase the number of its affiliates from 15 to 47, thus growing its membership from 30,000 to 71,000, with about an 88\% affiliation rate. The Hudson Valley Area Labor Federation (HVALF) was established to cover seven counties between Albany to its north and New York City to its south, excluding Westchester and Putnam Counties (which comprised their own central body). None of the counties in the HVALF jurisdiction had large enough cities or union memberships to support a functional central labor body. After its creation through the New Alliance process, the HVALF increased its affiliation from 31,000 to 63,000 members. Today, the New York State United Teachers - the largest AFT affiliate in the country with over 400,000 members - and

\footnotetext{
${ }^{18}$ Interview with Al Davidoff, September 29, 2005. Interview with Bruce Colburn, October 19, 2006.
} 
CSEA account for over 50\% of the HVALF membership. (These two public sector unions represent a significant percentage of union members in virtually all of the state's central bodies. $^{19}$

As noted earlier, efforts to restructure and revitalize the Long Island Federation of Labor (LIFoL) were deferred for several years after the launch of New Alliance in 1999. In 2004, the national AFL-CIO placed the two-county federation in trusteeship. Northeast Regional Director Joe Alvarez served as the trustee and facilitated a major reorganization. In 2005, John Durso, president of RWDSU 338, was elected LIFoL president, and Roger Clayman, a former Field Mobilization staff member, was hired as its executive director. With over 250,000 union members in Nassau and Suffolk Counties, the Long Island Federation - the nation's fourth largest central body - managed to increase its membership to about 120,000 by adding over 20,000 teachers and benefiting from CSEA's increasing its affiliation from 3,000 to $30,000 .{ }^{20}$

As the financial base and staff capacity of the area labor federations were expanded, they were gradually transformed into more highly functional central bodies. The central bodies devised formal strategic work plans so affiliate leaders understood how resources would be spent and staff deployed. This process was critically important in persuading key leaders of major affiliates to become engaged, to further increase their union's affiliation rates, and to lend their political clout and credibility to the area labor federations. ${ }^{21}$

\footnotetext{
${ }^{19}$ Interview with Colleen Gardner, April 25, 2006. Interview with Amy Desjardins, April 25, 2006.

${ }^{20}$ Interview with John Durso, President Long Island Federation of Labor, April 14, 2006. Interview with Roger Clayman, Executive Director Long Island Federation of Labor, April 25, 2006. Interview with Joe Alvarez, April 28, 2006.

${ }^{21}$ Interview with Joe Fox, President Capital District ALF, October 6, 2005. Interview with Kathleen Scales, Executive Director Capital District ALF, April 27, 2006. Interview with Tim Riley, President
} 
With their increased staff and resources, ALFs systematically built new capacities, primarily related to communicating with and mobilizing union members to support contract and organizing campaigns and, more commonly, to elect and engage endorsed political candidates. Formal mobilization plans were developed and mobilization structures were established. This capacity generally included functional phone banks, e-activist networks, letter writing and blast FAX systems, websites, newsletters, labor-to-neighbor efforts, “Street Heat” mobilizations, regular meetings of organizers and political coordinators, and greater cooperation among affiliated unions. These all represent key steps in the mobilizing stage of a central body's organizational development. $^{22}$

\section{Programmatic Work}

Every restructured area labor federation has utilized its enhanced capacity to engage in programmatic work that has begun to build the power of its local labor movement. This is also true for the Long Island Federation of Labor, which was not restructured through the New Alliance process, but was eventually strengthened over time in accordance with the principles that guided New Alliance. In general, this process has represented a qualitative change in central body activity and strategic direction. But today ALF leaders are quick to point out that as impressive as these changes have been, they represent only small steps in the right direction and that much more needs to be done

Hudson Valley ALF, May 5, 2006. Interview with Jen Fuentes, Field Coordinator Hudson Valley ALF, April 25, 2006.

${ }^{22}$ Interview with Amy Desjardins, April 25, 2006. The Capital District Area Labor Federation regularly publishes and distributes its "Workers in the News" newsletter. 
to move their organizations through the "power-building” stage of development toward “agenda-driving.",23

In many cases, the shift in programmatic work was guided by a strategic plan that the central body’s executive board developed through a formal process of deliberations and decision-making. Most area labor federations decided to begin their efforts by following the AFL-CIO’s 10-point political program, more or less closely and generally to good effect. This political program involved conducting one-on-one meetings with local union leaders to arrange the assignment of campaign coordinators from each affiliate; distributing monthly worksite flyers; coordinating a common message in affiliate newsletters; mailing political literature to union members; and, reaching the ALF base through targeted member-to-member canvass programs and phone banks. Virtually every ALF established a more rigorous endorsement process that included candidate interviews and comprehensive questionnaires. Candidates were - and still are - routinely asked about their views on the right to organize, a living wage, public education, privatization of public services, outsourcing, project labor agreements ${ }^{24}$, tax breaks, workers' compensation, Empire Zones ${ }^{25}$, economic development, state and local budgets, social security, universal health care, the right to strike, immigrant affairs, apprenticeship training, unemployment benefits, appointment of labor representatives to public boards and commissions, and other issues. This process not only enabled central body delegates to carefully vet candidates, to probe their positions on issues important to working

\footnotetext{
${ }^{23}$ Interview with John Durso, April 14, 2006. Interview with Tim Riley, May 5, 2006. Interview with Joe Fox, October 6, 2005.

${ }^{24}$ These are contracts between a government agency and/or a private developer and building trades councils.

${ }^{25}$ A program in New York State that gives tax breaks to companies that locate in areas of high poverty and unemployment.
} 
families, and to make more informed endorsement decisions. It also served as an educational tool for candidates who learned what really mattered to unions and why. ${ }^{26}$

Once endorsements were made, area labor federations coordinated with the NYS AFL-CIO to identify strategically important races and evaluate which ones were close and could be swung by labor. Then, the ALF's newly developed mobilization capacity was used to win those key electoral campaigns. ${ }^{27}$

This strategy worked for several ALFs. For example, in Ulster County, the Hudson Valley Area Labor Federation (HVALF) worked through two election cycles to shift a 21 to 10 Republican majority to a 16 to 15 Republican majority, and then to a Democratic majority in the county legislature. ${ }^{28}$

In 2001, the Westchester-Putnam Central Labor Body flipped a solid Republican majority in the Westchester County legislature to an 11 to 7 Democratic majority and helped re-elect the Democratic County Executive with 73\% of the vote, the highest majority in the county's history. ${ }^{29}$

After the revitalized Long Island Federation of Labor emerged from trusteeship, it helped elect a Democratic county executive and legislature in Nassau and Suffolk Counties, two traditionally solid Republican territories. William Lindsay, the former business manager of Long Island's largest IBEW affiliate, had been elected a Suffolk County legislator in 2001, and largely due to the labor movement’s growing political muscle, he became the Legislature's presiding officer in $2006 .^{30}$

\footnotetext{
${ }^{26}$ Interview with Paul Ryan, President Westchester-Putnam Central Labor Body, April 24, 2006. Interview with Amy Desjardins, April 25, 2006.

${ }^{27}$ Interview with Amy Desjardins, April 25, 2006.

${ }^{28}$ Interview with Tim Riley, May 5, 2006. Interview with Jen Fuentes, April 25, 2006.

${ }^{29}$ Interview with Paul Ryan, April 24, 2006.

${ }^{30}$ Interview with John Durso, April 14, 2006. Interview with Roger Clayman, April 25, 2006.
} 
After 37 years of Republican dominance in Schenectady, an old industrial city just west of Albany, the Capital District Area Labor Federation used its newly developed political capacity to help elect Democrat Brian Stratton as mayor as well as a Democratic city council and county legislature. According to Kathleen Scales, Executive Director of the ALF, this represented dramatic change in the political dynamics of Schenectady. ${ }^{31}$

The political strength of the statewide labor movement was demonstrated in the September, 2006 Democratic primaries, when Eliot Spitzer and Andrew Cuomo won for Governor and Attorney General, respectively, by decisive margins with union support.

Then, in the November 2006 elections, New York State unions helped deliver huge victories for Spitzer, Cuomo, and Senator Hillary Clinton. Perhaps even more impressive, two well established incumbent Republicans allied with President Bush were unseated from Congress by progressive Democrats, both of whom ran energetic grassroots campaigns driven in part by labor activists who tapped political skills developed in earlier local elections. Democrat John Hall, an anti-war environmentalist who is a member of the Musicians union, bumped Republican Sue Kelly in the $19^{\text {th }}$ Congressional District, and Democrat Kirsten Gillibrand beat Republican John Sweeney in the $20^{\text {th }}$ Congressional District. And, when Republican Congressman Sherwood Boelhert retired in the $24^{\text {th }}$ Congressional District, Democrat Michael Arcuri defied the odds in the traditionally Republican CD and was elected with the help of the Central New York and Rochester Area Labor Federations. These upset victories helped tip Congress to the Democratic Party. ${ }^{32}$

\footnotetext{
${ }^{31}$ Interview with Kathleen Scales, April 27, 2006.

${ }^{32}$ Interview Prairie Wells, Outreach Coordinator Capital District ALF, November 21, 2006. Interview with Amy Desjardins, November 27, 2006.
} 
By demonstrating their political power in important elections well before November, 2006, area labor federations were able to make demands on elected leaders and to enter policy arenas from which labor leaders had been largely excluded. This greater involvement and higher profile in public policy represented an important step in the direction of what some leaders call "regional power building.” In most areas, labor leaders had not just been excluded from the regional power structure, they had been only minimally conscious that the "governing regime" was not just confined to elected officials and public administrators. Rather, in most regions of the state, government leaders joined with private power brokers in formal and informal networks to determine public policies and economic strategies that served a corporate agenda. Playing a more decisive electoral role presented union leaders with a new opportunity: they could begin to challenge how the dominant regime governed and promote a countervailing political and economic agenda that would serve working communities rather than corporate elites.

That is precisely what area labor federations began to do across the state, although not uniformly. For example, in Ulster County, after flipping the county legislature, the Hudson Valley Area Labor Federation (HVALF) turned its attention to the Industrial Development Agency (IDA), a quasi-public body that makes consequential decisions about how public money and tax abatements are used to stimulate the local economy. The HVALF helped pass a non-binding resolution supporting the inclusion of prevailing wage language in the IDA's standards. Applying such standards to IDA-supported construction would require contractors performing work on those projects to pay local prevailing wages. Before the area labor federation had demonstrated its ability to impact local electoral races, the IDA had soundly rejected a similar prevailing wage resolution. 
After the Hudson Valley Area Labor Federation flexed its political muscle through two electoral cycles, it won formal labor representation on the IDA when Jen Fuentes, a fulltime HVALF staff person was appointed to serve on the board. Thereafter, the 27member Industrial Development Agency - whose members are appointed by the county legislature - not only passed the ALF-sponsored prevailing wage resolution unanimously, it established a community benefits matrix that rated companies seeking IDA tax abatements and helped protect both construction and non-construction workers from unscrupulous employers. Because the matrix also rewarded environmentally-friendly enterprises, this initiative strengthened the labor movement's relationship with other constituency groups, including environmentalists. In Sullivan County, the area labor federation successfully altered the composition of the county legislature and used its political influence to good effect when the state sought local approval for an Indian gaming initiative. Before the legislature endorsed the gaming proposal, a commitment was secured for both a project labor agreement on casino construction and card check recognition for casino employees. ${ }^{33}$

These kinds of public policy interventions were not entirely new for the labor movement in the Hudson Valley. For example, Tim Riley, the president of both the HVALF and IBEW Local 363, already served on the Rockland County IDA board, which had included prevailing wage language in its standards several years earlier. But the labor movement had historically been more influential in Rockland than the neighboring

\footnotetext{
${ }^{33}$ Interview with Jen Fuentes, April 25, 2006 and October 23, 2006. The community benefits point system rewards businesses applying for IDA support if the applicant company is clearly contributing to the economic well-being of the larger community.
} 
counties, and it was the area labor federation's growing political might that enabled it to become a public policy player in Ulster and Sullivan. ${ }^{34}$

Throughout the state, local labor leaders followed the same strategy deployed in the Hudson Valley: they used their area labor federation's electoral success as a platform to step into regional economic development and public policy. For example, after flipping the Westchester County Legislature, the central labor body there helped pass a county-wide living wage ordinance and is now working on progressive IDA reform legislation. $^{35}$

On Long Island, the labor federation followed its electoral successes by helping to pass a living wage bill in Nassau County and the nation's first Fair Share for Health Care legislation in Suffolk County. ${ }^{36}$

In Buffalo, the Western New York Area Labor Federation will likely supplant the Economic Development Group as the key regional body promoting a progressive social infrastructure and a high road economy. ${ }^{37}$

In Schenectady, NY, where the Capital District ALF helped win the mayoralty, city council and county legislature, a labor representative was finally appointed to the Metroplex Board, an important regional economic development agency. Prodded by its new member from the local labor movement, the board mandated that any and all construction it supported would be done under the terms of a project labor agreement that ensured the employment of union members. ${ }^{38}$

\footnotetext{
${ }^{34}$ Interview with Jen Fuentes, October 23, 2006. Interview with Tim Riley, May 5, 2006.

${ }^{35}$ Interview with Paul Ryan, April 24, 2006.

${ }^{36}$ Interview with John Durso, April 14, 2006. Interview with Roger Clayman, April 25, 2006

${ }^{37}$ Interview with Lou Jean Fleron, Cornell University School of Industrial and Labor Relations, May 12, 2006.

${ }^{38}$ Interview with Kathleen Scales, April 27, 2006.
} 
There are other similar examples from every region of the state. These all represent small but important steps in building the labor movement's regional power and positioning union leaders to help shape the public policies and economic strategies that will determine the quality of life working families enjoy. But to effectively move through the power building stage of organizational development toward agenda driving, the state's central labor bodies will also have to become more effective in growing the labor movement and more adept at building labor-community coalitions.

Building the capacity of area labor federations enabled them to provide more decisive labor and community support for affiliate contract and organizing campaigns. As compared to electoral fights, there are fewer examples of ALFs and CLCs offering this kind of support, largely because there have not been a great number of notable contract and organizing campaigns in New York State since the New Alliance restructuring. In some cases, the unions that conduct these kinds of campaigns tend to have significant capacity on their own and therefore are less likely to ask for or rely on the assistance available through the area labor federation. In other cases, smaller affiliates with limited capacity sometimes come to the ALFs or CLCs for support late in a campaign, when it is more difficult to save a losing fight.

In a number of cases, union leaders have engaged elected officials to help workers win in organizing and bargaining. State legislators demonstrated with Verizon VIS workers who were seeking a second contract with the company and waging an unfair labor practice strike. The mayor of Albany spoke directly with Verizon management and urged the company to settle the dispute, which it finally did. A statewide effort to organize home day care workers that involves the Civil Service Employees Association 
(CSEA) and the NYS and NYC teachers unions (NYSUT and UFT) will require state legislation to establish New York State as the employer of record. The unions can rely on elected leaders now friendly to labor to pass the necessary legislation and have already benefited from Joe Bruno, leader of the Republican controlled state Senate, publicly expressing his support for the workers. In the Town of Colonie, Republican and Democratic town council members persuaded the town supervisor to conduct an expedited card check recognition and contract negotiation that enabled EMT workers to win union representation with SEIU Local 200 United. There are other similar examples where local labor movements have leveraged their new-found political clout to advance union organizing and collective bargaining. ${ }^{39}$

Area labor federation leaders have also begun to play key roles in bringing affiliates together to cooperate and provide one another with mutual support. This is possible because ALF presidents increasingly enjoy greater credibility among fellow union leaders, credibility derived from the expanded capacity and effectiveness of the central labor body. For example, Hudson Valley Area Labor Federation President Tim Riley worked closely with state federation president Denis Hughes, to promote a more cooperative spirit between the building trades and SEIU. Last year, SEIU 1199 was organizing St. Lukes / Cornwall Hospital in Newburgh, N.Y., with which the building trades had a solid relationship. At that time, the hospital administration was following a long-standing policy of building and maintaining their facilities union. Riley and Hughes helped establish good lines of communication between the building trades and SEIU that led to the sharing of information about union health plans and other issues of mutual interest. Just demonstrating a willingness to communicate - without really ever

\footnotetext{
${ }^{39}$ Interview with Colleen Gardner, April 28, 2006.
} 
leveraging the building trades' relationship with the hospital - sent a message to the hospital administration that helped SEIU win the organizing campaign. When SEIU sought to negotiate its first collective bargaining agreement with the hospital, the building trades were prepared to mobilize their members for a solidarity rally, but that turned out to be unnecessary when the employer signed a union contract. Tim Riley would be the first to say that these were merely incremental steps in the right direction. But they did eventually lead to a Memorandum of Understanding between the building trades and $1199 .{ }^{40}$

Across the state, area labor federations have convened roundtable meetings of organizers to share experiences and explore opportunities for mutual assistance. Clearly, much more needs to be done to devise and drive a real growth strategy in New York State. But the ALFs provide one of the few venues where organizers from different unions can gather to strategize and support one another and one of the more effective means for unions to connect with allies outside the labor movement.

Every major central labor body in New York State has engaged in community outreach and coalition building as a vital element of its program. Setting up and/or supporting local chapters of Jobs With Justice, creating Workers’ Rights Boards, and cooperating with various social justice organizations have enabled ALFs to establish themselves as real players in their regions. The Capital District Area Labor Federation is a particularly good example. The ALF's first significant outreach effort took place in 2003 when it actively participated in the Immigrant Workers’ Freedom Ride (IWFR). Prairie Wells, the newly hired outreach coordinator, remembers to experience vividly. "At first, we resented the Freedom Ride and regarded it as a top-down mandate from

\footnotetext{
${ }^{40}$ Interview with Tim Riley, May 5, 2006. Interview with Jen Fuentes, October 23, 2006.
} 
Washington, D.C. that would be hard to do," she recalls. "But it turned out we were wrong. It put us in a position to champion an issue that many in our community cared deeply about. And, we were able to challenge the labor movement and improve our relationships with the larger community. Those relationships have lasted and progressed.” The ALF began its IWFR work with a process of discussion and education within the labor movement. According to Wells, it was difficult to achieve consensus on any particular policy issues given the diverse perspectives of ALF affiliates. But eventually unionists reached agreement on two basic points: hard working immigrants should not be exploited and their lives should be celebrated. Then, the ALF reached out to community groups, over thirty of which chose to work with the labor movement in welcoming the buses carrying immigrants from Chicago through Albany to New York City for a huge rally in Queens. Over fifty people representing a variety of organizations - ranging from the NAACP to the Hispanic Outreach Coalition, from the Green Party to the Catholic Diocese - participated in six months of regular meetings to plan a celebratory event to greet the NYC-bound buses. The event was held at the Soldiers' and Saliors’ Monument in Albany’s Washington Park and drew about 600 people. “It was amazing, unbelievable,” recounts Wells. “When the buses arrived it was just beautiful. We all broke into tears.” Every coalition partner had an opportunity to address the gathering and then the crowd marched with the immigrant workers from the park to a local church where the local religious community provided abundant food and a Latin DJ entertained the dancing throngs. The event achieved widespread media coverage and generated enormous good will between the labor movement and community allies. 
The area labor federation followed the Immigrant Workers Freedom Ride with a novel outreach initiative designed to bridge the generational and racial gaps between trade unionists and young workers. For three years, the CDALF has worked with a number of community groups in sponsoring an annual "Hip Hop Movement Meets the Labor Movement Cultural Festival.” Prairie Wells describes the planning process as a “wild, awesome experience” with consensus decision-making and a shared commitment to inclusion. The daylong festivals have featured breakdancing, graffiti, rapping, fashion and dancing and have attracted crowds of well over 1500 people. These events have cultivated new relationships that are likely to be helpful in unexpected ways. For example, building trades unionists are now exploring ways to improve their outreach and recruitment of apprentices from communities that have historically been excluded from construction careers.

More recently, the area labor federation has worked with a number of community groups to improve and expand civil rights protections at the city and county levels to cover victims of domestic violence, veterans and gender-variant individuals. A human rights coalition emerged out of this work and because the labor movement participated in a principled and effective way, its standing and credibility in the larger community were further enhanced.

“How does all this work fit into regional power building?” Prairie Wells asks herself. "You can’t be a power player if no one knows who you are. You need to be present, visible, credible.” This kind of community outreach and coalition building can be very challenging. According to Wells, if the labor movement is not a full, even driving partner, the work can be politically perilous. But it provides an opportunity for 
the labor movement to build credibility, establish a presence, and ultimately articulate a message that resonates with the 70\% of New York State's workers who still remain outside the ranks of organized labor and tend to regard it as a narrow self-interest group. $^{41}$

New York State’s central bodies have generally not been successful in establishing standards that affiliates must meet before accessing central body support for individual union struggles. Some, like the Capital District Area Labor Federation, have contemplated providing affiliates with graduated support that would escalate as unions requesting help met rising standards agreed upon by all ALF affiliates. These standards might conceivably include: greater lead time in seeking assistance, more advanced planning, more comprehensive strategies, dedicated staff and resources, and other criteria. Higher levels of central body support could be contingent on affiliates meeting these higher standards. If the state’s ALFs continue to grow their capacity to help affiliates win tough contract and organizing campaigns, and if affiliates recognize and appreciate the value of that assistance, the more functional central bodies could provide meaningful incentives for affiliates to meet higher standards themselves. This dialectical elevation of standards and capacity at the central body and within individual unions would likely enhance the chances of affiliate success. But this hasn't yet been done anywhere in New York State.

\section{Impact of National Split}

Throughout New York State, the national split has disrupted local labor movements, distracted local leaders from the good work they have been doing, and engendered feelings of frustration and resentment toward national leaders. Across the

\footnotetext{
${ }^{41}$ Interview with Kathleen Scales, November 20, 2006. Interview with Prairie Wells, November 21, 2006.
} 
state there has not been a uniform response to the original split. In some cases, Change to Win unions simply left the area labor federations and central labor councils immediately after July AFL-CIO convention in Chicago. In other cases, no changes were made, regardless of the directives issued from the national AFL-CIO.

In four area labor federations, the standing president is from a CTW union: Western New York, based in Buffalo (UFCW), Central New York, based in Syracuse (SEIU), Capital District, based in Albany (PEF [SEIU-AFT]), and Long Island (RWDSU-UFCW). In three ALFs or major CLCs, the president is from the IBEW: Hudson Valley, Westchester-Putnam, and New York City. The president of the NYS AFL-CIO, Denis Hughes, also comes out of the IBEW. At the New York City Central Labor Council, the treasurer, Ida Torres, is from RWDSU-UFCW.

Several months after the Chicago AFL-CIO Convention, the initial chaos and concern that many felt finally settled down with the agreement to allow Change to Win unions to maintain their membership in state and local bodies through Solidarity

Charters. When another conflict at the national level erupted following UFW's disaffiliation from the AFL-CIO, these Solidarity Charters threatened to unravel. Nevertheless, most local leaders want to continue to work together where they can and many feel prepared to do that regardless of the apparent inability of national leaders to negotiate arrangements that are acceptable on national level.

\section{Conclusion}

The New Alliance restructuring has helped to build more functional central bodies with the resources and capacity to pursue meaningful programmatic work and to move toward a regional power-building and agenda-driving orientation. Positive steps in a 
good direction have been taken, although they are generally small and incremental. It remains to be seen whether these steps are sufficient to help affiliates overcome the "free market trade unionism" that characterizes their current practice. But the restructured and revitalized area labor federations and central labor councils provide the only viable venues where affiliate leaders can come together to develop strategies that transcend the narrow interests of their own individual unions and serve the broader interests of the larger community. Whether the split in the national movement will continue to distract local leaders and divert them from a path toward regional power building also remains to be seen. If national leaders can't reach some accommodation, the likelihood is that they will become less and less relevant to local leaders who seem to be committed to maintaining unity and hopefully doing something progressive with that unity. 


\section{References / Interviews}

Joe Alvarez, former Northeast Regional Director AFL-CIO, April 28, 2006.

Susan Borenstein, National Field Representative AFL-CIO, July 31, 2006.

Roger Clayman, Executive Director Long Island Federation of Labor, April 25, 2006.

Al Davidoff, former New York State Director AFL-CIO, September 29, 2005 and October 20, 2006.

Amy Desjardins, Field Services New York State AFL-CIO, April 25, 2006.

John Durso, President Long Island Federation of Labor, April 14, 2006.

Lou Jean Fleron, Cornell University School of Industrial and Labor Relations, May 12, 2006.

Joe Fox, President Capital District Area Labor Federation, April 28, 2006.

Jen Fuentes, Field Coordinator, Hudson Valley Area Labor Federation, April 25, 2006.

Colleen Gardner, Organizing Director New York State AFL-CIO, April 25, 2006 and April 28, 2006.

Denis Hughes, President New York State AFL-CIO, April 26, 2006.

Tim Riley, President Hudson Valley Area Labor Federation, April 24, 2006.

Paul Ryan, President Westchester-Putnam Central Labor Body, April 24, 2006.

Kathleen Scales, Executive Director, Capital District Area Labor Federation, April 27 2006.

Prairie Wells, Outreach Coordinator, Capital District Area Labor Federation, November 21, 2006. 


\section{Addendum \#1}

Central Labor Council Organizational Development Chart (See separate attachment)

\section{Addendum \#2}

New York State Area Labor Federation and Central Labor Council Map

(See separate attachment) 